\title{
Assessment of assisted migration effects on spring bud flush in white spruce (Picea glauca [Moench] Voss] seedlings
}

\author{
by Pengxin $L u^{1,2}$ and Rongzhou Man ${ }^{1}$
}

\begin{abstract}
In a changing climate, delaying the time of bud flush may be advantageous to boreal forest species to reduce the risk of spring frost damage. In this study, we examined the potential effect of assisted migration of tree seed on time to bud flush for white spruce. Flushing times of seedlings from 23 white spruce provenances from Ontario were observed under varying temperature conditions simulated in controlled environment chambers. Results indicated that time to bud flush varied considerably among provenances. Although higher temperatures significantly promoted bud flushing for all provenances, provenance-by-temperature interactions were negligible, indicating stable performance of white spruce provenances for this adaptive trait. Spatial patterns of variation among provenances in bud flushing were not consistent with patterns found in range-wide provenance tests. Assisted migration of tree seed across relatively short distances is unlikely to delay bud flushing time in white spruce. Some southern populations may flush earlier at more northerly sites, which would exacerbate spring frost risk. Tree improvement may be an effective approach to utilize among- and withinprovenance variation to enhance this fitness trait for better climatic adaptation.
\end{abstract}

Key words: bud flush, provenance, frost damage

\begin{abstract}
RÉSUMÉ
À la suite d'un changement climatique, le report du débourrement des bourgeons pourrait s'avérer avantageux pour les espèces des forêts boréales en leur permettant de réduire le risque de gel printanier. Au cours de cette étude, nous avons étudié les effets potentiels de la migration forcée de semences dépinette blanche sur la période de débourrement. La période de débourrement de semis issus de 23 provenances dépinette blanche de l'Ontario a été observée selon des conditions de température variables simulées dans des pièces à environnement contrôlé. Les résultats ont indiqué que la période de débourrement des bourgeons varie considérablement selon la provenance. Même si des températures significativement plus élevées ont favorisé le débourrement des bourgeons pour toutes les provenances, les interactions entre la provenance et la température étaient négligeables, indiquant une performance uniforme des provenances dépinette blanche en fonction de cette caractéristique d’adaptation. Les patrons spatiaux de variation entre les provenances dans le cas du débourrement des bourgeons nont pas été constants par rapport aux patrons observés lors de tests de provenance sur l'ensemble de la distribution. La migration forcée des semences d'épinette sur de relativement petites distances ne devrait vraisemblablement pas retarder la période de débourrement des bourgeons de lépinette blanche. Certaines populations australes pourraient débourrer plus hâtivement dans des stations plus nordiques, ce qui pourrait exacerber les risques de gel printanier. Lamélioration génétique pourrait constituer une approche effective d'utilisation de la variation au sein d'une provenance et entre les provenances pour renforcer cette caractéristique d'adaptabilité aux conditions climatiques.
\end{abstract}

Mots clés : débourrement des bourgeons, provenance, dégât par le gel

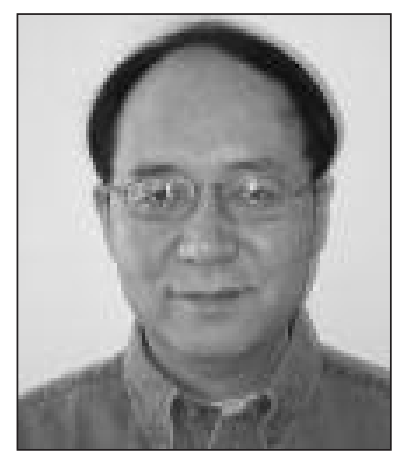

Pengxin Lu

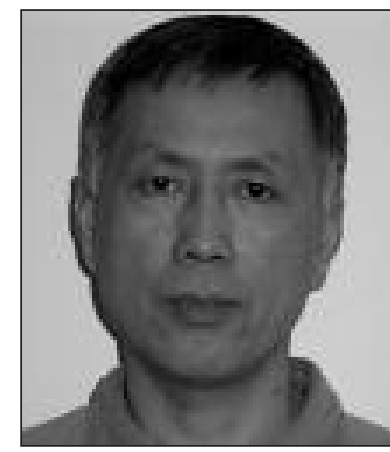

Rongzhou Man

\section{Introduction}

For boreal forest species, which are often subjected to unfavourable spring weather conditions, such as late spring frost, time to bud flush is an important adaptive trait (Bailey and Harrington 2006, Man et al. 2009). Dehardened buds or actively growing tree tissues can be severely damaged or killed at temperatures slightly below freezing (Glerum 1973, Bigras and Hébert 1996). When bud flushing is not synchronous with local climate, the vulnerability of trees to damage from late spring frost increases, which can result in losses of vigour and growth potential (Rehfeldt 1979, 1992; Matyas and Yeatman 1992).

A possible consequence of climate change is weather patterns that deviate from climate norms and more extreme vari-

\footnotetext{
${ }^{1}$ Ontario Ministry of Natural Resources, Ontario Forest Research Institute, 1235 Queen Street East, Sault Ste. Marie, Ontario P6A 2E5.

${ }^{2}$ Corresponding author: e-mail: pengxin.lu@ontario.ca
} 
ation in local weather (Astatkie et al. 2003). For example, seasonally low temperatures in early spring can be interrupted by a spell of warm days (Hänninen 2006). Earlier than normal bud flushing induced by warm temperature in spring can be detrimental to forest trees (Cannell and Smith 1986, Colombo 1998, Man et al. 2009), although examples to date are not well documented.

As an evolutionary consequence of adapting to local environment, most temperate and boreal forest species require a certain amount of heat accumulation, indicated by growing degree days (GDD) or growing degree hours (GDH), to break bud in the spring (Cannell and Smith 1983, Hannerz et al. 1999, Bailey and Harrington 2006). Among boreal coniferous species, white spruce (Picea glauca [Moench] Voss) requires fewer GDD to flush bud than other species, such as black spruce (Picea mariana [Mill.] BSP) (O'Reilly and Parker 1982) and red spruce (Picea rubens Sarg.) (Blum 1988), which may make it more likely to experience early bud flushing and therefore more vulnerable to late spring frost.

For tree species, such as several spruce and pine species, that have widespread natural distribution and that encounter varying climatic conditions across their range, substantial variability in growth and adaptation has been detected among geographic populations (Morgenstern and Mullin 1990; Matyas and Yeatman 1992; Li et al. 1993, 1997; Morgenstern and Copis 1998). When they are grown together in field trials, southern populations often flush later than those from more northern locations (Ekberg et al. 1994, Blum 1988, Partanen and Beuker 1999, Søgaard et al. 2008), which indicates that southern populations may require more GDDs. Data quantifying differences in the amount of heat required for bud flush under various conditions is sparse for white spruce.
Assisted migration of tree seed may mitigate some undesirable effects of maladaptation caused by climate change. For example, when southern populations are grown on more northerly sites while within the range of adaptation, the timing of bud flush may be delayed if their necessary GDDs are more than those required for local populations. To understand the potential effects of assisted migration on bud flush in white spruce, we examined the effects of seed origin on time to bud flush using seedlings from 23 geographic populations (provenances) of white spruce in Ontario under varying patterns of growing conditions simulated in controlled environment chambers.

\section{Methods}

Seedling culture

Seedlings from 23 white spruce provenances in Ontario, spanning the area from $45.73^{\circ} \mathrm{N}$ to $48.95^{\circ} \mathrm{N}$ in latitude and from $76.85^{\circ} \mathrm{W}$ to $93.93^{\circ} \mathrm{W}$ in longitude, were included in the study (Table 1; Fig. 1). Each provenance was represented by bulk seeds equally contributed by four to 10 wild trees. Climate norms (1970-2000) for the seed origins were derived using the SEEDWHERE software (McKenney et al. 1999).

White spruce seeds were sown in the greenhouse in early April 2008 and seedlings were grown in $3.8 \mathrm{~cm} \times 21 \mathrm{~cm} \mathrm{SC}$ 10 Super Cell tubes filled with 2:1 commercial peat moss/vermiculite (v/v) mixture. During the growing season, greenhouse conditions were maintained at a temperature regime of $26^{\circ} \mathrm{C}$ (day) $/ 18^{\circ} \mathrm{C}$ (night) and a 16 -h photoperiod. Seedlings were watered regularly and fertilized with 20-8-20 (N-P-K) (Plant Products Co Ltd, Brampton, ON) at 100 ppm N to promote growth and development. In early September 2008, seedlings were moved to a polyhouse where they stayed till

Table 1. Geographic locations and climate norms at the origins of provenances tested in this study

\begin{tabular}{|c|c|c|c|c|c|c|c|c|}
\hline Provenance & Latitude $\left({ }^{\circ} \mathrm{N}\right)$ & Longitude $\left({ }^{\circ} \mathrm{W}\right)$ & $\mathrm{AMT}^{\mathrm{a}}\left({ }^{\circ} \mathrm{C}\right)$ & GSL $^{\text {a }}$ (days) & $\operatorname{MaxT} 2^{a}\left({ }^{\circ} \mathrm{C}\right)$ & $\operatorname{MaxT}^{\mathrm{a}}\left({ }^{\circ} \mathrm{C}\right)$ & $\operatorname{MaxT} 4^{\mathrm{a}}\left({ }^{\circ} \mathrm{C}\right)$ & $\operatorname{MaxT} 5^{a}\left({ }^{\circ} \mathrm{C}\right)$ \\
\hline 8016 & 45.98 & 79.45 & 4.05 & 188 & -4.54 & 1.42 & 9.42 & 17.84 \\
\hline 8019 & 46.28 & 79.07 & 4.17 & 189 & -4.85 & 1.40 & 9.56 & 18.20 \\
\hline 8021 & 46.31 & 81.65 & 4.35 & 190 & -4.09 & 1.50 & 9.60 & 17.84 \\
\hline 8024 & 46.00 & 77.43 & 4.47 & 192 & -4.26 & 2.22 & 10.50 & 18.97 \\
\hline 8026 & 45.73 & 76.85 & 4.92 & 196 & -4.04 & 2.32 & 10.81 & 19.13 \\
\hline 8043 & 49.77 & 85.42 & 0.28 & 161 & -8.98 & -1.73 & 7.11 & 16.09 \\
\hline 8047 & 49.62 & 84.58 & 0.10 & 160 & -9.28 & -2.03 & 6.82 & 15.89 \\
\hline 8051 & 48.70 & 85.58 & 0.94 & 165 & -6.95 & -0.76 & 7.33 & 15.45 \\
\hline 8062 & 49.93 & 87.12 & -0.31 & 156 & -9.12 & -2.00 & 6.76 & 15.66 \\
\hline 8066 & 49.28 & 85.97 & 0.83 & 165 & -7.86 & -1.14 & 7.43 & 15.94 \\
\hline 8067 & 48.72 & 85.87 & 1.35 & 168 & -6.44 & -0.61 & 7.26 & 14.97 \\
\hline 8097 & 48.95 & 93.93 & 2.71 & 180 & -6.20 & 0.88 & 10.08 & 18.38 \\
\hline 8162 & 46.55 & 81.97 & 3.58 & 184 & -4.92 & 0.78 & 8.99 & 17.46 \\
\hline 8163 & 47.25 & 79.52 & 2.46 & 179 & -7.01 & -0.56 & 7.92 & 16.91 \\
\hline 8184 & 48.32 & 81.55 & 1.57 & 169 & -7.11 & -0.58 & 7.83 & 16.78 \\
\hline 8185 & 47.78 & 80.42 & 2.04 & 174 & -7.15 & -0.62 & 7.88 & 16.95 \\
\hline 8188 & 48.58 & 81.62 & 1.40 & 168 & -7.32 & -0.73 & 7.70 & 16.68 \\
\hline 8190 & 47.90 & 79.57 & 2.03 & 176 & -7.38 & -0.64 & 7.80 & 17.02 \\
\hline 8703 & 47.98 & 84.78 & 2.34 & 177 & -5.14 & 0.26 & 7.70 & 15.09 \\
\hline 8704 & 47.17 & 84.58 & 2.97 & 180 & -4.55 & 0.74 & 7.77 & 15.44 \\
\hline 8705 & 46.33 & 82.50 & 4.47 & 193 & -4.20 & 1.25 & 9.15 & 17.21 \\
\hline 8706 & 46.47 & 82.23 & 3.91 & 187 & -4.69 & 0.94 & 9.05 & 17.38 \\
\hline 8712 & 47.68 & 81.72 & 2.01 & 172 & -6.51 & -0.17 & 8.14 & 16.99 \\
\hline
\end{tabular}

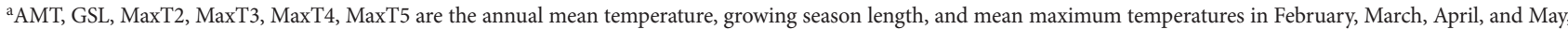
respectively. 


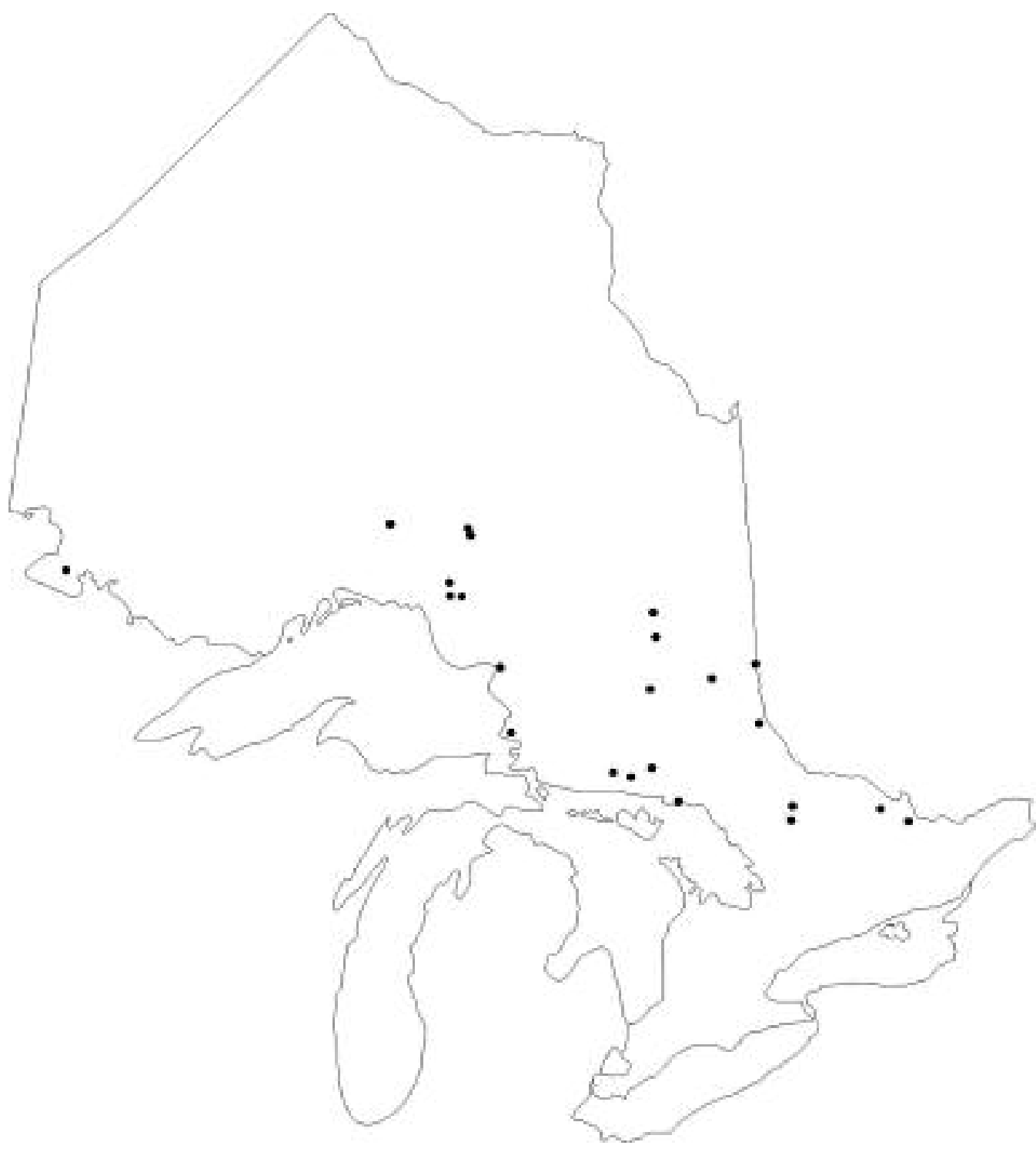

Fig. 1. Distribution of white spruce provenances that were used in the bud flush study.

mid December and the temperatures and photoperiod followed ambient conditions $\left(3^{\circ} \mathrm{C}\right.$ to $9^{\circ} \mathrm{C}$ day $/ 1^{\circ} \mathrm{C}$ to $8^{\circ} \mathrm{C}$ night $)$. Fertilization rates were adjusted to $20-20-20$ at $50 \mathrm{ppm} \mathrm{N}$ with higher concentrations of $\mathrm{P}$ to promote hardening off of buds. By mid-September, fertilization was discontinued but watering continued as needed.

In mid-December, the container seedlings were wrapped in plastic bags, boxed, and stored at $-3^{\circ} \mathrm{C}$ for one month (midDec. to mid-Jan.). In the following month (mid-Jan. to midFeb.), seedlings were stored at $2^{\circ} \mathrm{C}$ to continue the chilling treatment.

On February 17, seedlings were moved from cold storage to computer-controlled growth chambers/growth rooms for the bud flush experiment. Six temperature treatments were applied (Table 2): Treatments 1, 3, and 6 represented low, medium, and high temperature conditions for bud development. Treatments 2 and 5 mimicked a pattern of increasing seasonal temperature, while Treatment 4 simulated periodic freezing during the period of bud flush.

\section{Experimental design and data collection}

A split-plot experimental design was used, with temperature treatments (6 levels) randomly applied to the whole-plots (i.e., growth chambers and growth rooms) and provenances randomly applied to the split-plots. The experiment was replicated twice at the whole-plot level. In total, 12 growth chambers/rooms were used and 1,514 seedlings were tested, with five to six seedlings per provenance replicated within each of the whole plots.

The occurrence of terminal bud flush was recorded twice a day (at 10:00am and 3:00 pm, respectively) for each individual seedling for approximately eight weeks from the start of the bud flush experiment until all seedlings had broken bud. Following Murray et al. (1989) and Bigras and Hébert (1996), 
Table 2. Temperature treatments applied to white spruce provenances during bud flush (photoperiod was constant at 16-h day and 8-h night]

\begin{tabular}{cl}
\hline Treatment & Temperature regime \\
\hline 1 & $0^{\circ} \mathrm{C}$ (night) $/ 10^{\circ} \mathrm{C}$ (day) throughout experiment \\
2 & $\begin{array}{l}\text { Started at } 0^{\circ} \mathrm{C} \text { (night) } / 10^{\circ} \mathrm{C} \text { (day), with a } 3^{\circ} \mathrm{C} \\
\text { increase in both temperatures every } 6 \text { days }\end{array}$ \\
3 & $5^{\circ} \mathrm{C}$ (night) $/ 15^{\circ} \mathrm{C}$ (day) throughout experiment \\
4 & $5^{\circ} \mathrm{C}$ (night) $/ 15^{\circ} \mathrm{C}$ (day), with a 4-hour exposure to - \\
& $2^{\circ} \mathrm{C}$ every 3 days until first bud break \\
5 & $5^{\circ} \mathrm{C}$ (night) $/ 15^{\circ} \mathrm{C}$ (day), interspersed with an 8 -h \\
& exposure to $20^{\circ} \mathrm{C}$ every 3 days until end of experi- \\
& ment \\
& $10^{\circ} \mathrm{C}$ (night) $/ 20^{\circ} \mathrm{C}$ (day) throughout experiment. \\
\hline
\end{tabular}

a bud was considered flushed when the terminal bud had broken scales and green foliage was visible.

The accumulation of thermal time to budburst for individual seedlings was calculated as the summed product of growing degree hours (GDH) (Nienstaedt 1974, O'Reilly and Parker 1982, Colombo 1998, Bailey and Harrington 2006) above a base temperature of $1^{\circ} \mathrm{C}$ from the time the seedlings were put into the growth rooms/chambers (February 17). A base temperature of $1^{\circ} \mathrm{C}$ and GDH were used because a prior study indicated that the base temperature of $1^{\circ} \mathrm{C}$ was superior to that of $5^{\circ} \mathrm{C}$ and GDH was more accurate than GDD in differentiating the time to bud flush for white spruce seedlings (Man and Lu 2010).

\section{Statistical analyses}

A mixed linear model was used to detect the fixed effects of temperature treatments and the random effects of provenances and their interactions on time to bud flush:

$$
\text { [1] } Y_{i j k l}=\mu+R_{i}+T_{j}+R T_{i j}+P_{k}+T P_{j k}+e_{i j k l}
$$

where, $Y_{i j k l}$ is the thermal time calculated for the $1^{\text {th }}$ seedling of $\mathrm{k}^{\mathrm{ik} k \mathrm{~h}}$ provenance in the $\mathrm{j}^{\text {th }}$ temperature treatment in the $\mathrm{i}^{\text {th }}$ replication; $\mu$ is the overall mean; $R_{i}$ is the effect of the $\mathrm{i}^{\text {th }}$ replication $(\mathrm{i}=1,2) ; T_{j}$ is the effect of the $j^{\text {th }}$ temperature treatment $(\mathrm{j}=1,2, \ldots 6) ; R T_{i j}$ is the interaction between the $\mathrm{i}^{\text {th }}$ replication and the $j^{\text {th }}$ temperature treatment (experimental error for the whole-plot effects); $P_{k}$ is the effect of the $\mathrm{k}^{\text {th }}$ provenance; $T P_{j k}$ is the interaction between the $\mathrm{j}^{\text {th }}$ temperature and the $\mathrm{k}^{\text {th }}$ provenance; and $e_{i j k l}$ is the residual of the $1^{\text {th }}$ seedling of $\mathrm{k}^{\text {th }}$ provenance in the $\mathrm{j}^{\text {th }}$ temperature treatment in the $\mathrm{i}^{\text {th }}$ replication. The Mixed Procedure of SAS (SAS Institute Inc. 2008) was used to partition the variances of random effects and test the significance of fixed effects in eq. 1 . The predicted values of GDH and the days to bud flush (DTBF) for each of the provenances were related to geographic coordinates and climate norms of the provenance origins to detect spatial patterns of provenance variation in time to bud flush.

\section{Results and Discussion}

\section{Effects of temperature on time to bud flush}

Temperature regimes significantly influenced the timing of bud flush in white spruce seedlings. Across provenances, buds flushed earlier and more uniformly under warmer growing conditions, with the average DTBF decreasing with increasing temperature, i.e., the average number of days to complete bud flush from least to most was: T6 $<\mathrm{T} 5<\mathrm{T} 3<\mathrm{T} 4<\mathrm{T} 1$ (Table 3). An exception was Treatment 2, which had a lower starting, but steadily increasing temperature, which seemed to enhance heat use efficiency, resulting in earlier bud flush at lower GDH than expected relative to the other treatments (Tables 2 and 3). More details about the effects of growing temperature on bud flush of white spruce seedlings are reported elsewhere (Man and Lu 2010).

\section{Effects of provenance on time to bud flush}

Considerable variation in bud flushing, indicated by both GDH and DTBF, was detected among the 23 white spruce provenances tested. Provenance accounted for $12 \%$ to $13 \%$ of total phenotypic variation in bud flush variables (Table 4), which is almost equal to the proportion reported for provenance effects on growth traits; and is substantially higher than the proportion reported for bud flush from previous white spruce provenance studies using field trials, which included provenances from eastern Ontario and Quebec (Li et al. 1993, 1997; Lesser and Parker 2004). It is possible that the twicedaily monitoring of bud flushing in this study provided more accurate estimates of GDH requirements and DTBF for individual provenances than the twice-weekly monitoring common in other studies. Because seedlings completed bud flush in about 18 days under warm temperatures (e.g., Treatment 6 in Table 3), short observation intervals are desirable when studying bud flushing in white spruce, although this may be inconvenient or impractical for field trials.

The difference in DTBF between the means of the fastest and the slowest flushing provenances was 3.3 to 9.3 days, depending on temperature treatment (Table 3). Under low temperatures (e.g., Treatment 1), which mimicked the average daily temperature in May for most of the provenances under study (climate norms can be found at: http:// climate.weatheroffice.gc.ca/climate_normals/index_e.htm, provided by the National Climate Data and Information Archive, Environment Canada), the treatment mean DTBF was prolonged to 35 days and the largest difference in DTBF among provenance means was 9.3 days. Under higher growing temperatures (e.g., $5^{\circ} \mathrm{C}$ (day) $/ 15^{\circ} \mathrm{C}$ (night)), which mim-

Table 3. Means of growing degree hours (GDH) and days to bud flush (DTBF) and the ranges among provenance means across temperature treatments

\begin{tabular}{|c|c|c|c|c|c|c|c|}
\hline & & \multicolumn{6}{|c|}{ Temperature treatment ${ }^{\mathrm{a}}$} \\
\hline & & 1 & 2 & 3 & 4 & 5 & 6 \\
\hline $\mathrm{GDH}$ & $\begin{array}{l}\text { Mean } \\
\text { Range }\end{array}$ & $\begin{array}{c}5054 b^{\mathrm{b}} \\
1343\end{array}$ & $\begin{array}{c}4718 b \\
1201\end{array}$ & $\begin{array}{c}6907 a \\
1330\end{array}$ & $\begin{array}{c}6945 a \\
1372\end{array}$ & $\begin{array}{c}6686 a \\
1789\end{array}$ & $\begin{array}{c}6781 a \\
2455\end{array}$ \\
\hline DTBF & $\begin{array}{l}\text { Mean } \\
\text { Range }\end{array}$ & $\begin{array}{c}35.0 a \\
9.3\end{array}$ & $\begin{array}{c}20.6 c \\
3.3\end{array}$ & $\begin{array}{c}27.1 b \\
5.5\end{array}$ & $\begin{array}{c}27.6 b \\
5.3\end{array}$ & $\begin{array}{c}24.9 b \\
6.4\end{array}$ & $\begin{array}{c}18.0 c \\
6.5\end{array}$ \\
\hline
\end{tabular}

a Temperature treatments are defined in Table 2.

${ }^{\mathrm{b}}$ Values within rows with the same letter indicate non-significant difference based on Fisher's least-significant-difference (LSD) test at $\alpha=0.05$. 
icked the average daily temperatures in June, a spread of five to six days in average DTBF was observed among provenances. Such a spread between the fastest and the slowest bud flushing provenances can be meaningful in developing adaptation strategies if this trait is highly inheritable at the provenance level. Similar variation in bud flushing time among provenances was previously reported from a three-year-long range-wide provenance trial in Wisconsin (Blum 1988). Information on provenance variation in GDH and DTBF is, however, scarce for white spruce, as for most tree species.

Provenance-by-temperature interaction accounted for less than $2.6 \%$ of the total phenotypic variation in bud flush traits of white spruce seedlings (Table 4). This indicates that provenance ranking in different temperate regimes was fairly stable. This is consistent with results in a reported field trial in Quebec (Li et al. 1993, 1997), which indicated no significant provenance-by-site interaction for bud flush in third-year seedlings. Considering the substantial variation among provenances in time to bud flush and the moderate to strong genetic control over bud flush in coniferous species (Hannerz et al. 1999, Jermstad et al. 2003, Søgaard et al. 2008), it seems possible that patterns of bud flush in white spruce can be altered by provenance selection in reforestation programs, whether to promote or delay bud flushing in the spring based on management objectives.

\section{Spatial patterns of variation in time to bud flush}

Geographic patterns of variation in bud flush were generally weak for the white spruce provenances tested in this study. Pearson correlation coefficients between bud flush traits and geographic coordinates or the climate norms of seed origins were mostly insignificant (Table 5). This was inconsistent with the results reported from a range-wide provenance trial of white spruce (Blum 1988), which indicated that provenances of northern origin flushed bud earlier than those of southern origin. In fact, data from this study indicated a weak pattern that was the reverse of trends reported from the range-wide provenance test. For example, some more southerly provenances initiated and completed bud flush earlier than the northern ones in this study as evidenced by the
Table 4. Estimates of variance components for growing degree hours (GDH) and days to bud flush (DTBF) in the white spruce provenance bud flush study (with the proportion of total phenotypic variance in parentheses]

Variance component $(\%)$

\begin{tabular}{lcccc}
\hline Trait & $\begin{array}{c}\text { Provenance } \\
(\mathbf{P})\end{array}$ & $\mathbf{P} \times$ Temp. & Residual & $\begin{array}{c}\text { Intra-class } \\
\text { correlation }\end{array}$ \\
\hline GDH & 89991 & 12023 & 594186 & 0.88 \\
& $(12.93)$ & $(1.73)$ & $(85.35)$ & - \\
DTBF & 1.2933 & 0.2538 & 9.3174 & 0.83 \\
& $(11.90)$ & $(2.54)$ & $(85.76)$ & - \\
\hline
\end{tabular}

trend of negative correlations between GDH and growing season length (GSL) or between GDH and the mean maximum daily temperature at seed origin from February through April (MaxT2 through MaxT4) (Table 5), which suggested that some southern provenances actually used fewer GDH than the northern ones. Because southerly provenances are generally subject to longer growing seasons and higher maximum daily temperatures between January and May, the correlations between bud flush traits (GDH or DTBF) and the climate norms of seed origins (e.g., GSL, AMT, MaxT2 through MaxT4) would have been positive, had the southern provenances required more GDH to flush bud. In fact, in temperature treatments 1 and 3 , some of the Pearson correlation coefficients between bud flush traits and climate norms of seed origin were significantly negative $(\mathrm{P}<0.05)$. Similarly, Li et al. (1997) found that Julian days to date of bud burst in the third growing season was positively correlated to latitude, indicating that northerly provenances took more days to flush bud than some southerly provenances did.

The discrepancy in geographic patterns of variation between Blum's (1988) range-wide provenance test and our regional genecology study does not necessarily reflect conflicting results, but rather different sampling schemes. The

Table 5. Pearson correlation coefficients between provenance means of bud flush traits GDH and DTBF) and mean climatic variables (1970-2000) of provenance origins for white spruce provenances tested in this study

\begin{tabular}{|c|c|c|c|c|c|c|c|c|c|}
\hline Parameter & $\begin{array}{l}\text { Temp. } \\
\text { treat. }\end{array}$ & $\begin{array}{c}\text { Latitude } \\
\left({ }^{\circ} \mathbf{N}\right)\end{array}$ & $\begin{array}{c}\text { Longitude } \\
\left({ }^{\circ} \mathbf{W}\right)\end{array}$ & $\begin{array}{c}\text { AMT } \\
\left({ }^{\circ} \mathrm{C}\right)\end{array}$ & $\begin{array}{c}\text { GSL } \\
\text { (days) }\end{array}$ & $\begin{array}{c}\text { MaxT2 } \\
\left({ }^{\circ} \mathrm{C}\right)\end{array}$ & $\begin{array}{c}\text { MaxT3 } \\
\left({ }^{\circ} \mathrm{C}\right)\end{array}$ & $\begin{array}{c}\text { MaxT4 } \\
\left({ }^{\circ} \mathrm{C}\right)\end{array}$ & $\begin{array}{c}\text { MT5 } \\
\left({ }^{\circ} \mathrm{C}\right)\end{array}$ \\
\hline \multirow[t]{6}{*}{$\mathrm{GDH}$} & 1 & 0.233 & -0.121 & -0.223 & -0.307 & $-0.409^{*}$ & -0.370 & -0.268 & -0.091 \\
\hline & 2 & -0.088 & -0.270 & -0.060 & -0.064 & -0.033 & -0.039 & -0.063 & 0.006 \\
\hline & 3 & 0.319 & -0.089 & -0.391 & $-0.416^{*}$ & $-0.462^{\star}$ & $-0.457^{\star}$ & $-0.427^{\star}$ & -0.295 \\
\hline & 4 & -0.099 & $-0.413^{*}$ & 0.019 & -0.039 & -0.103 & -0.068 & -0.022 & 0.106 \\
\hline & 5 & -0.145 & -0.123 & 0.028 & -0.289 & -0.164 & -0.158 & -0.152 & -0.088 \\
\hline & 6 & -0.202 & -0.278 & 0.232 & 0.141 & 0.073 & 0.167 & 0.233 & 0.309 \\
\hline \multirow[t]{6}{*}{ DTBF } & 1 & 0.233 & -0.121 & -0.224 & -0.307 & $-0.409^{*}$ & -0.370 & -0.269 & -0.091 \\
\hline & 2 & -0.072 & -0.267 & -0.075 & -0.081 & -0.052 & -0.057 & -0.079 & -0.004 \\
\hline & 3 & 0.318 & -0.087 & -0.388 & $-0.414^{*}$ & $-0.462^{*}$ & $-0.456^{\star}$ & $-0.425^{\star}$ & -0.291 \\
\hline & 4 & -0.100 & $-0.413^{\star}$ & 0.019 & -0.038 & -0.102 & -0.068 & -0.022 & 0.106 \\
\hline & 5 & 0.041 & -0.281 & -0.134 & -0.157 & -0.175 & -0.169 & -0.162 & -0.098 \\
\hline & 6 & -0.201 & -0.277 & 0.231 & 0.140 & 0.073 & 0.167 & 0.233 & 0.309 \\
\hline
\end{tabular}

Note: Climate variables are defined in Table 1, temperature treatments are described in Table 2.

* indicates Pearson correlation coefficient was significantly different from zero at $\alpha=0.05$. 


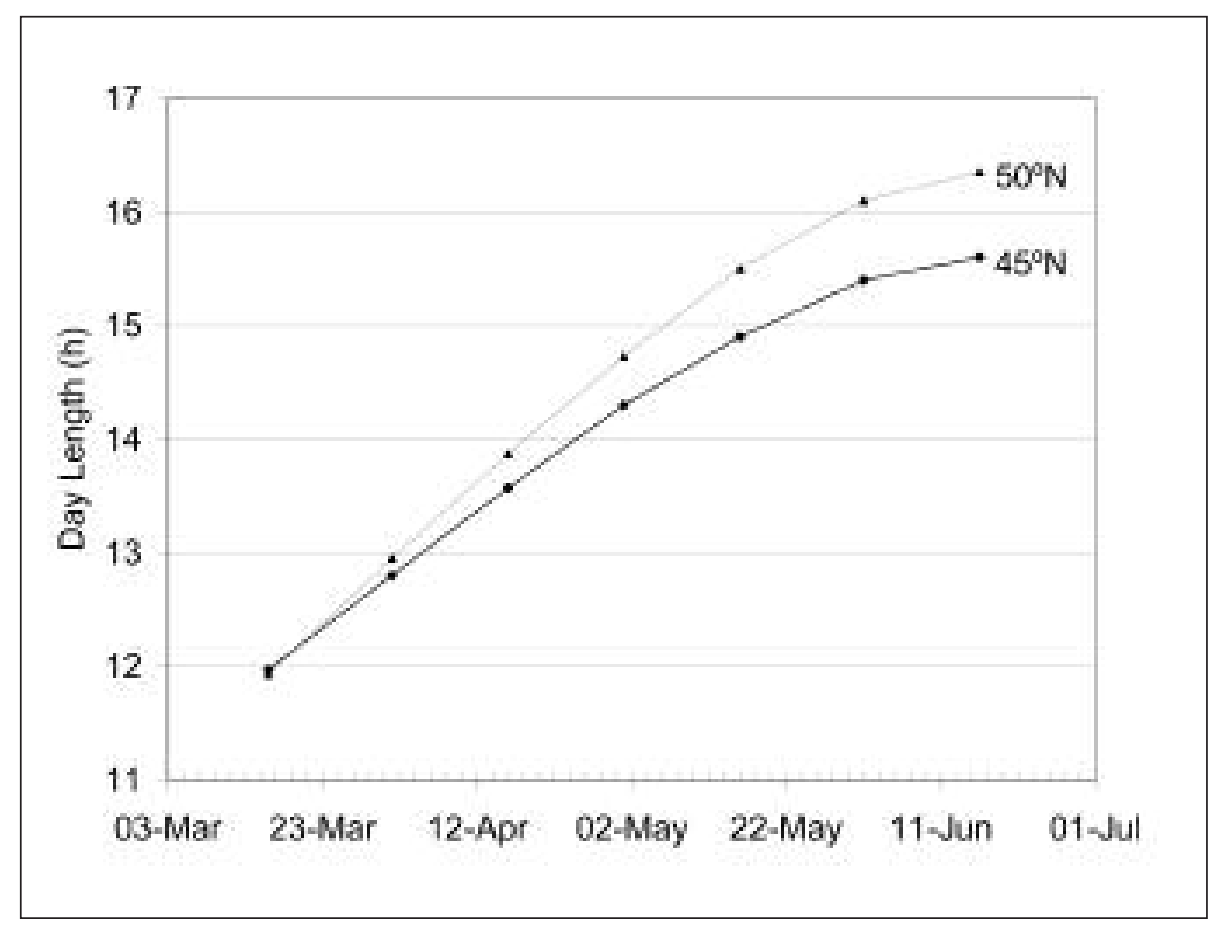

Fig. 2. Day length (hours) at the northern $\left(50^{\circ} \mathrm{N}\right)$ and southern $\left(45^{\circ} \mathrm{N}\right)$ origins of the provenances from March 16 to June 16.

range-wide provenance trial sampled provenances sparsely to cover a large gradient of environmental variation, while our regional genecology studies sampled local populations more intensively within a limited environmental gradient and thus revealed finer-scale differences. While information from the range-wide provenance trial provides insight to genetic variability at large scales and at a species level, it may not be reflective of regional trends as the natural distribution of white spruce is large and variation among local populations is substantial (as it is revealed in this study). When data from the white spruce range-wide provenance trial (Blum 1988) are reexamined with a focus on specific regions, the range-wide trend of variation in bud flush is lost due to random variation among local provenances. Since operational seed transfer in forest trees is likely to be limited to short distances to avoid mal-adaptation (Ying and Yanchuk 2006), information from local genecology studies can be of direct value to seed source planning for forest regeneration programs.

It was noted that this study used a constant 16 -h photoperiod in the bud flush experiment, to which the provenances of white spruce may have responded differently. Although photoperiod was believed to play a lesser role, compared with temperature, during dormancy release and bud flush (Hänninen 1990, Worrall 1993), some studies indicated that long days may compensate the lack of chilling during rest break (Nienstaedt 1967) and shorten the time to bud burst (Partanen et al. 1998). In the current study, provenance origins spanned about $5^{\circ}$ latitude, which suggests that these provenances would naturally experience different photoperiods during bud development and flush in the spring. Fig. 2 shows the length of natural photoperiods at the latitude of $45^{\circ} \mathrm{N}$ and $50^{\circ} \mathrm{N}$, respectively, from March 16 through June 16 (data obtained from http://www.sci. fi/ benefon/sol.html). The 16-h photoperiod used in this study had apparently surpassed the length of natural photoperiod for almost all provenances, with larger differences for the more southerly provenances. If similar effects of photoperiod on bud flush exist in white spruce as it does in Norway spruce (Partanen et al. 1998), bud flush could have been promoted more for the more southerly provenances than the more northerly ones under the 16-h day-length. In such case, this study may have underestimated GDH requirements for more southerly provenances; consequently, under estimating the potential benefits of assisted migration in delaying bud flush time. However, assisted migration that moves seed northward would also make southerly populations to experience longer photoperiod during bud development and flush, which may trade off, to some degree, the impact of the 16-h day length on the assessment of the potential effects of assisted migration on spring bud flush in white spruce seedlings. In an earlier study of white spruce seedlings, Pollard and Ying (1979) found that different photoperiod treatments ( $8 \mathrm{~h}$ vs. $16 \mathrm{~h}$ ) did not affect the rankings in bud flush time among white spruce families.

Results from this and an earlier study (Li et al. 1997) on bud flushing of white spruce with provenances sampled from eastern Ontario and Quebec have suggested that an assisted migration that moves bulk seeds northward over a relatively short distance would probably produce negligible or no gain on this fitness trait, because bud flush time is unlikely to be delayed. While geographic trends of provenance variation over a larger distribution area of white spruce (Blum 1988, Lesser and Parker 2004) suggest that assisted migration may delay bud flush, such prediction may not be materialized unless long-distance seed transfer is feasible. Over a short geographic distance, within which safe seed transfer is more likely, the above trends can be lost or even reversed as indicated by this and the previous study (Li et al. 1997). Nevertheless, all published studies on bud flush time of white spruce (Blum 1988; Li et al. 1993, 1997; Lesser and Parker 2004) have indicated considerable genetic variation among white spruce provenances. Pollard and Ying (1979) further revealed significant family differences in bud flush time within local white spruce stands in southern Ontario. Appreciable gain in delaying bud flush time is thus achievable through tree improvement programs, using a provenance and family-withinprovenance selection scheme. Of course, bud flush is only one of the fitness traits that need to be considered in seed transfer or tree improvement programs. 


\section{Conclusions}

Results from this study indicated that although bud flush time varied among the white spruce provenances tested, the late flushing provenances were mostly not of southerly origin, which did not follow the trends reported from a range-wide provenance test. Moving seeds northward in relatively short distance may not reduce the risk of spring frost damage by delaying time to bud flush. There is a possibility that frost damage risk may be exacerbated by earlier than expected bud flush of some southern populations growing on more northerly sites. This study indicates the possibility of delaying bud flush time through tree improvement programs and the ongoing need for better understanding of provenance genecological variation in fitness traits to guide any future attempts to move southern seed sources northward in response to climate change.

\section{Acknowledgements}

We thank D. Derbowka, S. Blake, K. Maloney, and S. Stuart, Ontario Ministry of Natural Resources (OMNR), for their assistance with the experiments; Dr. D. McKenney and K. Lawrence of the Canadian Forest Service - Great Lakes Forestry Centre for assistance with SEEDWHERE applications; and L. Buse, Dr. S. Colombo, OMNR, and two anonymous reviewers, for critical review and editorial assistance on an earlier version of this manuscript.

\section{References}

Astatkie, T., E.K. Yiridoe and J.S. Clark. 2003. Testing for trend in variability of climate data: measures and temporal aggregation with applications to Canadian data. Theor. Appl. Climat. 76: 235-247. Bailey, J.D. and C.A. Harrington. 2006. Temperature regulation of bud-burst phenology within and among years in a young Douglasfir (Pseudotsuga menziesii) plantation in western Washington, USA. Tree Physiol. 26: 421-430.

Bigras, F.J. and C. Hébert. 1996. Freezing temperatures and exposure times during bud break and shoot elongation influence survival and growth of containerized black spruce (Picea mariana) seedlings. Can. J. For. Res. 26: 1481-1489.

Blum, B.M. 1988. Variation in the phenology of bud flushing in white and red spruce. Can. J. For. Res. 18: 315-319.

Cannell, M.G.R. and R.I. Smith. 1983. Thermal time, chill days and prediction of bud burst in Picea sitchensis. J. Appl. Ecol. 20: 951-963. Cannell, M.G.R. and R.I. Smith. 1986. Climate warming, spring budburst and frost damage on trees. J. Appl. Ecol. 23: 177-191.

Colombo, S.J. 1998. Climatic warming and its effect on bud burst and risk of frost damage to white spruce in Canada. For. Chron. 74: 567-577.

Ekberg, I., G. Eriksson, G. Namkoong and C. Nilsson. 1994. Genetic correlation for growth rhythm and growth capacity at age 3-8 years in provenance hybrids of Picea abies. Scand. J. For. 9: 25-33.

Glerum, C. 1973. Annual trends in frost hardiness and electrical impedance for seven coniferous species. Can. J. Plant Sci. 53: 881-889. Hannerz, M., J. Sonesson and I. Ekberg. 1999. Genetic correlations between growth and growth rhythm observed in a short-term test and performance in long-term field trials of Norway spruce. Can. J. For. Res. 29: 768-778.

Hänninen, H. 1990. Modelling bud dormancy release in trees from cool and temperate regions. Acta For. Fenn. 213: 1-47.

Hänninen, H. 2006. Does climatic warming increase the risk of frost damage in northern trees? Plant Cell Environ. 14: 449-454.

Jermstad, K.D., D.L. Bassoni, K.S. Jech, G.A. Ritchie, N.C. Wheeler and D.B. Neale. 2003. Mapping of quantitative trait loci controlling adaptive traits in coastal Douglas fir. iii. quantitative trait loci-by-environment interactions. Genetics 165: 1489-1506.

Lesser, M.R. and W.H. Parker. 2004. Genetic variation in Picea glauca for growth and phenological traits from provenance tests in Ontario. Silvae Genet. 53: 141-148.

Li, P., J. Beaulieu and J. Bousquet. 1997. Genetic structure and patterns of genetic variation among populations in eastern white spruce (Picea glauca). Can J. For. Res. 27: 189-198.

Li, P., J. Beaulieu, A. Corriveau and J. Bousquet. 1993. Genetic variation in juvenile growth and phenology in a white spruce provenance-progeny in Québec. Silvae Genet. 42: 52-59.

Man, R., G.J. Kayahara, Q.L. Dang and J.A. Rice. 2009. A case of severe frost damage prior to budbreak in young conifers in Northeastern Ontario: Consequence of climate change? For. Chron. 85: 453-462.

Man, R. and P. Lu. 2010. Effects of thermal model and base temperature on the estimates of thermal time to bud break in white spruce (Picea glauca (Moench) Voss) seedlings. Can. J. For. Res. 40: $1815-1820$.

Matyas, C. and C.W. Yeatman. 1992. Effect of geographic transfer on growth and survival of jack pine (Pinus banksiana Lamb.) provenances. Silvae Genet. 41: 370-376.

McKenney, D.W., B.G. Mackey and D. Joyce. 1999. SEEDWHERE: A computer tool to support seed transfer and ecological restoration decisions. Environ. Model. Softw. 14: 589-595.

Morgenstern, E.K. and P. Copis. 1998. Best white spruce provenances in Ontario. Can. For. Serv., Ottawa, ON. Inf. Rep. No. ST-X16. $34 \mathrm{p}$.

Morgenstern, E.K. and T.J. Mullin. 1990. Growth and survival of black spruce in the range-wide provenance study. Can. J. For. Res. 20: 130-143.

Murray, M.B., M.G.R. Cannell and R.I. Smith. 1989. Date of budburst of fifteen tree species in Britain following climatic warming. J. Appl. Ecol. 26: 693-700.

Nienstaedt, H. 1967. Chilling requirements in seven Picea species. Silvae Genet. 16: 65-68.

Nienstaedt, H. 1974. Degree day requirements for bud flushing in white spruce - variation and inheritance. In Proceedings of the $8^{\text {th }}$ Central States Forest Tree Improvement Conference, October 11-13, 1972, Columbia, MO. pp. 28-32.

O'Reilly, C. and W.H. Parker. 1982. Vegetative phenology in a clonal seed orchard of Picea glauca and Picea mariana in northwestern Ontario. Can J. For. Res. 12: 408-413.

Partanen, J. and E. Beuker. 1999. Effects of photoperiod and thermal time on growth rhythm of Pinus sylvestris seedlings. Scand. J. For. Res. 14: 487-497.

Partanen, J., V. Koski and H. Hännien. 1998. Effects of photoperiod and temperature on timing of bud burst in Norway spruce (Picea abies). Tree Physi. 18: 811-816.

Pollard, D.F.W. and C.C. Ying. 1979. Variance in flushing among and within seedling white spruce. Can. J. For. Res. 9: 517-521.

Rehfeldt, D.E. 1979. Ecological adaptation in Douglas-fir (Pseudotsuga menziesii var. glauca) populations. 1. North Idaho and Northeast Washington. Heredity 43: 383-397.

Rehfeldt, D.E. 1992. Early selection in Pinus ponderosa: compromises between growth potential and growth rhythm in developing breeding strategies. For. Sci. 38: 661-677.

SAS Institute Inc. 2008. SAS/STAT user's guide, Version 9.2 edition. SAS Institute Inc., Cary, NC.

Søgaard, G., Ø. Johnsen, J. Nilsen and O. Junttila. 2008. Climate control of bud burst in young seedlings of nine provenances of Norway spruce. Tree Physiol. 28: 311-320.

Worrall, J. 1993. Temperature effects on bud-burst and leaf-fall in Subalpine larch. J. Sustain. For. 1: 1-18.

Ying, C.C. and A.D. Yanchuk. 2006. The development of British Columbia's tree seed transfer guidelines: purpose, concept, methodology, and implementation. For. Ecol. Manage. 227: 1-13. 